\title{
DOES CORPORATE GOVERNANCE MATTER IN THE MARKET RESPONSE TO MERGER ANNOUNCEMENTS? Evidence from the U.S. and Germany
}

\author{
Paul Lowengrub, ${ }^{a}$ Torsten Luedecke, ${ }^{\mathrm{b}}$ and Michael Melvin ${ }^{\mathrm{c}}$
}

January 2003

${ }^{a}$ CapAnalysis, Washington, D.C., USA

${ }^{\mathrm{b}}$ University of Karlsruhe, Karlsruhe, Germany

${ }^{\mathrm{c} A r i z o n a}$ State University, Tempe, Arizona, USA 


\title{
DOES CORPORATE GOVERNANCE MATTER IN THE MARKET RESPONSE TO MERGER ANNOUNCEMENTS? Evidence from the U.S. and Germany
}

\begin{abstract}
This paper attempts to determine if differences in corporate governance standards between Germany and the U.S would cause differences in the market response to merger announcements. German executives can deliberately make misleading statements regarding merger activities while U.S. executives must either state "no comment" or else provide a truthful statement. A sample of German and U.S. firms that announced acquisition plans in the 1995-1999 period was collected to determine if such a difference exists. Results over all firms in the sample suggest that merger news has no significant impact on cumulative abnormal returns for German firms but a significant positive impact for U.S. firms. Such results are consistent with the market having discounted the German price impact prior to announcements as may occur with insider trading while U.S. announcements are truly price-relevant news. A finer breakdown of the sample reveals that German-U.S. firm differences are not as simple as the aggregate results suggest. Specifically, larger firms in Germany and the U.S. have similar experiences. In addition, controlling for size it is found that German firms listed on a U.S. stock exchange also have similar experiences as U.S. firms. This is likely due to the greater disclosure requirements for such firms. So differences only exist between smaller firms in the U.S. and smaller German firms that are not traded on a U.S. exchange. Aside from this smaller-firm effect, the evidence is consistent with no price-relevant differences arising from the differences in corporate governance rules.
\end{abstract}




\section{DOES CORPORATE GOVERNANCE MATTER IN THE MARKET RESPONSE TO MERGER ANNOUNCEMENTS? Evidence from the U.S. and Germany}

\section{INTRODUCTION}

This paper addresses the following question: Does the market response to a merger announcement depend upon the regulations applying to corporate disclosure? Cross-country differences in securities laws and enforcement result in countries where firm executives must answer public questions about merger talks truthfully or else offer "no comment" while in other countries it is possible to make statements that the public may view as misleading. Laws and enforcement practices in the United States allow a response of "no comment," but if an agent of a firm chooses to speak about a merger, no misleading statements are permitted. In other countries, securities laws and their interpretation allow for potentially misleading statements by firm executives. Germany offers an example in this regard. Under German practice, an agent may choose to make statements that may be viewed by investors as misleading. Because of the institutional

differences, Germany and the United States form a useful cross-country pair to examine the market response to merger announcements in the context of their corporate governance differences.

These differences are illustrated in a recent case brought in New York federal court. A group of investors sued Deutsche Bank and its CEO, Rolf-Ernst Breuer, claiming that he misled the public on Deutsche Bank intentions regarding the takeover of Bankers Trust Corp. Takeover speculation had led Bankers Trust's stock price to rise about 30 percent in one week. In an interview that appeared in the German news 
magazine Der Speigel on October 26, 1998, Mr. Breuer commented that no merger was forthcoming. On that day, Bankers Trust's stock price fell 6 percent. After the takeover was publicly announced on November 29 , the shareholders filed a class action lawsuit against Deutsche Bank, claiming that they had sold the stock in response to Mr. Breuer's comments. Under U.S. law, if Deutsche Bank was, indeed, involved in takeover negotiations, Mr. Breuer was obliged to either make no statements, or else no misleading statements. This is because of the U.S. Surpreme Court ruling in 1988, which stated that a firm could be sued if it falsely denied engaging in merger negotiations. For this reason, U.S. executives routinely state "no comment" when asked if they are engaged in takeover negotiations.

The New York judge ruled that a key to the Deutsche Bank case was the meaning of the German word "Übernahmegespräche". ${ }^{1}$ The plaintiffs' translator stated that Übernahmegespräche "encompasses a spectrum of talks about a takeover ranging from preliminary, exploratory talks up through and including the formal structured talks understood by ..[the defendants]." The defendants' translator stated that Übernahmegespräche "refers to a relatively advanced stage of discussions between the two business entities contemplating the purchase of one by the other." The emphasis of the translations reflects the fact that past U.S. cases have depended upon whether talks were in preliminary or advanced stages. This is a case where U.S. law is interpreted and enforced differently than German law. In Germany, Mr. Breuer's statements did not set off a controversy and legal challenge.

\footnotetext{
${ }^{1}$ A good description of the case is found in the Wall Street Journal article "Lawsuit Hinges on a Wordand What a Word!" February 12, 2002, p. C1.
} 
The case of E.On AG, which as a former entity, Veba AG was sued for fraud by the U.S. Securities and Exchange Commission (SEC) for, allegedly, misleading investors by denying merger talks with Viag AG (only days before the merger was announced) represents another example of differences in German-U.S laws regarding merger statements. Following the SEC's inquiry into the Veba denial, German regulators announced that the SEC inquiry is of no concern in Germany as denying merger talks is not a violation of any German law.

Recently, U.S. attorneys filed a lawsuit against Deutsche Telekom alleging that the company misled investors who bought a new issue of American depositary receipts by not disclosing that it was in advanced talks to buy VoiceStream. The stock offering was on June 19, 2000, and then on July 24, 2000, Deutsche Telekom announced the takeover. The above cases illustrate the differences in how German and U.S. firms provide public information prior to a takeover.

As described above, the differences in corporate governance laws in these two markets make for an interesting case study of the impact of merger news. One would expect that takeover announcements by U.S. firms are more likely to be news and, therefore, embedded in price than in the case of German firms, where the closely-held nature of firms and greater likelihood of insider trading would provide a greater opportunity for trading ahead of the announcement.

To explore the issues raised above, the paper will proceed as follows. Section II provides a brief overview of important differences between U.S. and German securities market regulations and practices. Section III presents evidence related to the effect of 
merger announcements in Germany and the United States. Finally, Section IV provides a summary and conclusions. 


\section{OVERVIEW OF DIFFERENCES BETWEEN GERMAN AND U.S. REGULATIONS AND PRACTICES}

This paper does not attempt to provide a comprehensive view of differences in regulations and practices between German and U.S. securities markets. Such an undertaking goes well beyond the scope of this paper. ${ }^{2}$ The goal in this section is to highlight the important differences that may affect the impact of merger announcements on share prices. This is accomplished by offering a brief overview of key areas.

\section{Insider Trading}

In 1994, German law established a definition of prohibited insider-trading activities. This was considered a major step, as it was the first time that a legal mandate was specifically established. Prior to the insider-trading law, Germany relied upon voluntary self-regulation as a deterrent to insiders profiting from their private information. In the United States, case law has been used to establish what is considered to be inappropriate behavior by insiders. The U.S. experience does not rely on a list of activities prohibited by government decree, but on the evolving history of case outcomes to establish culpability.

Major banks in Germany assume a key role in the oversight of insider trading. ${ }^{3}$ Because of the important role that universal banks play in block share holding and corporate control in Germany, they are in a key monitoring position. Major banks are

\footnotetext{
${ }^{2}$ Useful papers in this area are Boehmer (1999) and (2000).

3 The German banking industry is dominated by the universal banks, which engage in all types of banking business. They may be grouped into three categories, according to their legal form: Private commercial banks, cooperative banks (Volks- und Raiffeisenbanken), and public-sector banks .
} 
required to have a compliance officer monitor material events that confer inside information, while at the same time, monitoring security transactions by bank employees. Any questionable activities are to be reported to the federal supervisory office in charge of enforcement. Because insider trades must become public information, executives of U.S. firms are required to report security trades to the SEC.

The U.S. SEC requires anyone guilty of insider-trading to disgorge ill-gained profits. In addition, fines and/or prison sentences may be levied. German law does not require the guilty to return the profits from insider trading, but the guilty parties typically offer to return profits voluntarily as a sign of goodwill to the court to increase the chance of no significant punishment. The German court may order the guilty to make a charitable contribution and can also impose imprisonment. Injured parties suffering damages from insider trading may bring civil suits in both Germany and the United States.

In a recent article devoted to estimating the effect of insider trading laws on the cost of capital across countries, Bhattacharya and Daouk (2002) rated countries from 0 (worst) to 5 (best) in terms of shareholder rights. Countries with a ranking of 5 included Hong Kong and the United States. Countries with a ranking of 1 included Colombia, Jordan, Venezuela, Switzerland, and Germany. The fact that two of the wealthiest countries in the world, Germany and the United States, have such different investor protection systems makes for a particularly interesting sample for our purposes. Role of Banks and Large Blockholders

Universal banks in Germany play a much larger role in corporate matters than in the United States. Major German banks act as lenders, underwrite share issues, hold 
major equity positions, serve as stock exchange market makers, hold corporate board positions, and exercise proxy votes for shares held by small shareholders. This allows the major banks to have a significant advantage in monitoring corporate management performance. Boehmer (2000) analyzed whether the presence of large blockholders and universal banks in Germany, are better situated to oversee management decisions and ensure the quality (and present value) of takeover decisions. This would be in contrast to the U.S. case of more diffused ownership and less oversight of management by shareholders (although with some offsetting benefit of more U.S. minority shareholder protection). Boehmer (2000) finds that majority owners are not associated with better takeover decisions, but large blockholders with less than 50 percent controlling interest do serve an important monitoring role. In particular, if a bank holds the second- or thirdlargest stake then takeover quality is improved by their oversight (in terms of shareholder wealth). The most value-reducing takeovers, however, are associated with cases where a bank holds the largest stake in an acquiring firm. In this sense, large bank blockholders do not guarantee better management decisions and may, in fact, be associated with worse decisions from the minority shareholders' perspective.

\section{Role of Labor and Corporate Control}

German law concerning "Mitbestimmung" or codetermination requires that any corporation with at least 500 employees must reserve 50 percent of the seats on its supervisory board (board of directors) for employee representatives. As with large corporations in the United States, the board oversees and approves major management decisions. Unlike boards in the United States, the German board reduces shareholders' rights to control board voting and oversight of the firm's assets. In the United States, it is 
generally thought that those who bear the risks of a firm's performance in terms of equity should have control over outcomes. While there is always debate over the reality of U.S. separation of management and ownership, Germany has institutionalized separation via the worker influence on the board. In addition to the issue of ownership and control, the broader representation on the German board may permit greater leakage of important corporate decisions prior to public knowledge.

\section{Accounting Regulations}

U.S. and German accounting regulations differ in terms of pension costs, goodwill, asset reserves, asset revaluation, foreign currency translation, and tax issues. Also, German firms are not required to provide a cash flow statement in their financial statements. Key differences between U.S. Generally Accepted Accounting Principles (GAAP) and German were highlighted when Daimler-Benz listed on the New York Stock Exchange in 1993. Such listings require filing financial statements with the SEC that fully conform to U.S. GAAP. Under German accounting standards, Daimler-Benz reported a 1993 profit of DM168 million. Under U.S. GAAP, the firm reported a loss of almost a billion marks for the same period. While it is known that such dramatic outcomes as in the Daimler Benz case are not generally found, it serves to underscore that the quality of public disclosure may differ considerably across countries when firms are held to different accounting standards.

\section{Public Disclosure of Takeovers}

Before January 1995, German acquirers were not required to publicly announce their interests in acquiring another company. As discussed in Boehmer (2000), acquirers were required to notify the target management if they intended to acquire more than 25 
percent of the target's voting rights. No public announcement or statement to target shareholders was required. This changed in January 1995, when firms listed on the German stock market faced a public notification requirement. As discussed in the introduction, while Germany has a regulation requiring public disclosure, this regulation has been interpreted quite liberally, so that public statements may not be made until the deal is arranged. Further, a German executive may deny takeover rumors even though negotiations are ongoing. This may allow for a long window of opportunity for insiders to exploit the knowledge that takeover talks are progressing. As stated in the introduction, U.S. firms must disclose truthfully if they make any public statements regarding takeover talks or else state "no comment. 


\section{EMPIRICAL ANALYSIS}

In this section we examine the differences in the market response to takeover announcements in Germany and the United States. We will first discuss the methodology used for estimation and then discuss the data set before proceeding to the results.

\section{Methodology}

We use a standard event-study methodology to estimate abnormal returns around takeover announcements. Our event period is from 5 days prior to the news to 5 days after the news. Normal returns are established by estimating a standard market model for a pre-event sample of 150 business days prior to the event period. The model estimated is:

(1) $R_{i t}=a_{i}+b_{i} R_{m t}+e_{i t}$ with $E\left(e_{i t}\right)=0$ and $\operatorname{Var}\left(e_{i t}\right)=\sigma_{e i}^{2}$

where $R_{i t}$ denotes the return on firm $i$ 's stock at time $t ; R_{m t}$, the market return at time $t$; $a$ and $b$ are coefficients to be estimated and $e$ is the error term for security $i$. With the coefficient estimates $\hat{a}$ and $\hat{b}$ from equation (1), the abnormal return during the event period is given by:

(2) $A R_{i t}=R_{i t}-\hat{a}_{i}-\hat{b}_{i} R_{m t}$

A t-statistic for the abnormal returns is found by dividing $A R_{i t}$ by the estimated standard error of the regression $\sigma_{e i}^{2}$.

Hypothesis tests on the abnormal returns for a cross-section of firms can be performed by averaging the abnormal returns across firms for each day in the event 
period: $A R_{t}=\sum_{i} A R_{i t} / N$, where $N$ is the number of firms. Tests of the persistence of the abnormal return can be performed on the cumulative abnormal return, which is the sum of the daily abnormal returns between the period $t 2-t 1: C A R_{i, t 2-t 1}=\sum_{t=t 1}^{t 2} A R_{i t}$. Hypothesis testing is based upon the following $\mathrm{Z}$ score: $Z=\frac{C A R}{\left(\sigma_{i}^{2}(t 2-t 1)\right)^{1 / 2}} \sim N(0,1)$, where $\sigma_{i}^{2}=(t 2-t 1+1) \sigma_{e i}^{2}$.

\section{Data}

We assembled a sample of German and U.S. firms that announced acquisition plans over the 1995-1999 period. 1995 was chosen as the starting year because the insider-trading law in Germany was instituted in 1994 and in force all of 1995. First, we compiled a list of all U.S. acquirer firms listed on the New York Stock Exchange (NYSE) in the United States and all German acquirer firms listed as public companies in Germany. The U.S. data source is the SCD Worldwide Mergers and Acquisitions database. The German data are from the Bundeskartellamt. Next, we identified the largest 50 U.S. acquirer firms in terms of market capitalization and the top 50 German acquirer firms in terms of trading volume. There were some problems with determining firm size correctly in Germany, but the stock volume data are not open to interpretation and indicate those German firms that command significant attention from investors.

Table 1 lists the German acquirer firms along with the date of the announcement, and the target firm. Table 2 provides the same information for the U.S. firms.

Daily closing stock prices were gathered for each U.S. firm from the Center for Research in Security Prices (CRSP) and used to estimate the abnormal returns. The 
market return for the U.S. firms is taken as the S\&P 500 index return and the market index for the German firms is the DAX 100. The estimation for each firm uses only nonoverlapping periods. The results may be biased if the "normal" return period for one firm event includes the day of another event for that firm. ${ }^{4}$ As can be seen in Tables 1 and 2, big acquirer firms are involved in multiple mergers during our sample period.

\section{Estimation Results}

In order to efficiently summarize a large number of estimation results, we first present the cross-firm average cumulative abnormal returns (CARs) for the merger news event day (day 0 ) and 5 days before and after the event day in Figures 1a and 1b. Two standard error bounds are drawn around the CARs. Figure 1a illustrates that in the case of abnormal returns for German firms, the CARs are all positive and on days -3 and 0 one can reject the hypothesis that the CARs equal zero. For U.S. firms, Figure $1 \mathrm{~b}$ shows that the CARs are statistically significantly negative for days -4 to 0 and then significantly positive on days 3 to 5 . So a cross-firm average of CARs suggests that the market anticipates the merger news in both countries, although the effect of an anticipated merger is negative for U.S. firms and positive for German firms. Then on the day of the news, the CAR is positive for share prices in Germany but for the U.S., prices remains negative. In the U.S. case, there is a follow-on effect in days after the news of a positive impact on share prices.

One interpretation of the results summarized in Figures $1 \mathrm{a}$ and $1 \mathrm{~b}$ is that the abnormal returns in Germany before the merger announcement properly anticipate the effect of the news as there is a positive CAR on day -3 and then a positive CAR on the

\footnotetext{
${ }^{4}$ However, we find that the results using all observations are qualitatively the same as those with only nonoverlapping observations.
} 
event day. So German trading prior to the event may reflect a proper discounting of the forthcoming event. In the U.S. case, the abnormal returns reflect trading prior to the news that appears to incorrectly anticipate the sign of the CAR associated with the merger news as the cumulative effect of the news by day 3 , continuing through day 5 is positive. So U.S. trading in anticipation of the merger news effect on share prices appears to incorrectly anticipate the ultimate effect. Then a few days of "correction" appears to follow the news to offset the earlier negative abnormal returns.

To gain further insight into the implications of these findings, cross-section regressions are estimated across all individual firms with fixed-effects for country. Additionally, the country dummies are interacted with a size dummy to determine if large firms experience a different abnormal return pattern than small firms. We define a firm as large by a market capitalization that is in the top one-third of our sample. This includes German (U.S.) firms with a market capitalization greater than $\$ 25$ (\$75) billion. ${ }^{5}$ Table 3 contains the estimation results.

Table 3 is split into three parts. Table 3 a reports results for the CARs over the five-day period prior to the news. Table $3 \mathrm{~b}$ reports the abnormal return event day results. Table 3c contains CAR results for the five-day period following the merger news. Table 3a, shows that the negative CARs depicted in Figure $1 \mathrm{~b}$ for the U.S. firms prior to the event day reflect a smaller-firm effect. For the largest U.S. firms, the CARs are positive. For these pre-announcement days, large U.S. firms have similar results to those of German firms. The interactive term, German*Big, indicates that the largest German

\footnotetext{
${ }^{5}$ The non-overlapping event sample contains 391 observations which includes 52 German firms, of which 16 had a market capitalization greater than $\$ 25$ billion. There are 52 German firms since Daimler Benz and Daimler Chrysler and Hoechst and SGL Carbon are included as individual entities. There are 50 U.S. firms, with 16 having a market capitalization greater than $\$ 75$ billion.
} 
firms have larger CARs than the smaller German firms, but all German firms experience CARs that are statistically significantly greater than zero.

Table $3 \mathrm{~b}$ indicates that on the day of the merger news, German and U.S. firms have similar effects. Larger firms have significantly larger abnormal returns on the event day than smaller firms, but firms in both countries experience positive abnormal returns on average.

Table $3 \mathrm{c}$ indicates that on the five days following the merger news, smaller German firms experience negative CARs on average. The larger German firms have positive CARs so this difference in sign between large and small German firms is why Figure 1a presented CARs for all German firms that did not differ significantly from zero. Larger U.S. firms have larger CARs than smaller U.S. firms, but both classes of U.S. firms experience positive CARs on average.

The overall message of Table 3 seems clear; the largest firms in both countries experience similar patterns of abnormal returns around merger news. This is a pattern of a positive impact on share prices before the merger announcement, on the day of the announcement, and in days following the announcement. The differences come from smaller firms. The results indicate that smaller firms in the US have negative CARs in the pre-announcement period while smaller German firms experience positive CARs. Then in the post-announcement period, smaller German firms experience negative CARs while smaller U.S. firms experience positive CARs.

Implications of Results

At first glance the empirical results suggest that there are no differences in corporate governance between Germany and the United States in the market response to 
merger news. The discussion in sections I and II might suggest that insider trading is more likely in Germany or investors are more likely to be misled by German corporate officers around merger events. The empirical results in section III, however, indicate that for the largest firms, the behavior of share prices around merger news is the same for German and U.S. firms. So there is nothing in the results for the largest firms to indicate any difference across countries.

Smaller firms in each country do have some systematic differences in share price behavior around merger news. U.S. smaller firms have negative CARs, on average, prior to the news while German smaller firms have negative CARs after the news day, on average. In the pre-event window, the evidence is consistent with trading based on better information in Germany than in the U.S., as German price movements appear to correctly anticipate the abnormal return on the news day while U.S. trading results in CARs with the opposite sign from the news day effect. Then in the post-announcement window, the negative CAR for smaller German firms partially offsets the earlier positive CARs. Smaller U.S. firms have statistically significant positive CARs after the event that more than offset the earlier pre-event negative CARs. This is consistent with the U.S. news having a larger permanent effect on share prices than in Germany for smaller firms.

The fact that the only qualitative differences between German and U.S. acquirer firms is for smaller firms, may indicate that the larger firms have no price-relevant differences in corporate activities around mergers. One factor that would contribute to this similarity between large firms in each country would be for large German firms to have stock listings in the United States and, therefore, more closely follow U.S. disclosure standards. To determine if this is a factor, we examine which German firms 
were listed in the U.S. stock market. Since firms that list in the U.S. must disclose information that differs from what is required domestically, it is possible that, rather than size, it is this greater disclosure that explains the similarities between large German and large U.S. firms. Twenty three of the German acquirer firms used for estimation were also listed in the U.S. Of the 27, seven are listed on the New York Stock Exchange and must comply with the same rules and regulations as U.S. firms. ${ }^{6}$ Five of these seven firms are in the category of "big" German firms while two (Fresenius Medical Care and SGL Carbon) firms fall in the smaller firm category. To test for an independent effect of a U.S. listing, cross-section models are estimated with the incorporation of an additional explanatory variable, German*USlist. This variable interacts the dummy variable for German location with a dummy variable for listing on a U.S. stock exchange. Table 4 reports these results.

In Table 4, the evidence indicates that accounting for a U.S. listing does not reduce the significance of the size effect. So apart from German firms that must report financial statements conforming to U.S. GAAP, there is an independent effect of large firms having larger abnormal returns. The coefficient on the interactive term for U.S.listed firms from Germany differs over the three sample periods. There is a negative effect prior to the news day, a positive effect on the news day, and a negative effect following the news day. All effects have p-values of 0.00 . The most interesting finding is that German firms that are traded on the New York Stock Exchange look like U.S. firms in terms of the patterns of abnormal returns. In the pre-announcement window,

\footnotetext{
${ }^{6}$ These include: BASF, Daimler Benz, Deutsche Telekom, Fresenius Medical Care AG, SAP AG, SGL Carbon AG, and Veba AG. The other U.S. listed firms are traded in the OTC market or are Rule 144a ADRs and therefore exempted from the full disclosure rules applied to exchange-listed firms.
} 
there is a negative effect for both the U.S. and German*USlist dummies and then both of these coefficients turn positive in the announcement and post-announcement windows. So besides large firms in each country having similar effects of a merger announcement, those German firms that are listed on a U.S. exchange also behave like U.S. firms. The only difference that exists between German and U.S. firms around merger announcements is for smaller firms, where German firms not listed on a U.S. exchange have positive CARs pre-news and negative CARs post-event while U.S. firms have negative and then positive CARs for the pre- and post-event periods respectively.

Given the statistically significant pre-announcement effects for both country samples, one cannot say that the merger news was unexpected. However, the fact that the pre-news-day U.S. effect for smaller firms was opposite in sign to the news-day and postnews-day effects is consistent with the market anticipating the merger news to adversely effect firm value. Yet the actual effect of the announcement is seen to be associated with positive abnormal returns. So information in the U.S. in the pre-news period does not seem to be as good as in the case of Germany where smaller firms have pre-news abnormal returns that accurately anticipate the news-day effect. However, in the German case, the post-event negative CAR is consistent with some reversion to the prior price level as if the market had overreacted to the expected announcement effect. 


\section{CONCLUSIONS}

It is well known that differences exist between German and U.S. corporate governance standards. This is particularly noteworthy in the area of disclosure around merger events. German executives can deliberately make misleading statements regarding merger activities while U.S. executives must either state "no comment" or else provide a truthful statement. The major focus of the research in this paper is to determine whether these differences in disclosure standards result in different share price behavior around merger news.

A sample of German and U.S. firms that announced acquisition plans in the 19951999 period was collected to determine if such a difference exists. The year 1995 was chosen as the starting period due to the insider-trading law passed in Germany in 1994. Measures of abnormal returns were created over the period from five days prior to five days after the merger news. Cumulative abnormal returns averaged across all firms indicates that the merger news event is associated with a positive impact for U.S. firms and no significant impact for German firms. So the most aggregated evidence is consistent with the market having already discounted the merger news in Germany so that the announcement is really not price-relevant "news." This is the sort of effect one might expect if insider trading occurred prior to the announcement event. The aggregated evidence for U.S. firms is consistent with the merger news causing significantly positive cumulative abnormal returns suggesting that the news impact was not already fully discounted by the market. 
A finer breakdown of the sample provides some evidence that the differences between German and U.S. firms is not as simple as just suggested. The evidence indicates that larger firms in Germany and the U.S. have similar experiences. The cumulative abnormal returns are positive both before and after the merger news and there is also a positive abnormal return on the news day. Controlling for this large firm effect, we also find that German firms that are traded on a U.S. stock exchange behave like smaller U.S. firms. There is a negative cumulative abnormal return prior to the merger news event and then a positive event day abnormal return followed by a positive post-event cumulative abnormal return. Only for smaller German firms not listed on a U.S. exchange do results differ. In this case, there is a positive cumulative abnormal return in the pre-event period and then a negative cumulative abnormal return in the post-event period. Smaller U.S. firms have just the opposite pattern.

The results for larger firms and those German firms that are traded on a U.S. stock exchange indicate that there is no generalized difference between the market response to merger news between German and U.S. firms, despite the distinct differences in rules relating to disclosure and public statements. While market participants are rightly concerned over investor protection and corporate governance rules, the bottom line on merger announcements is generally suggestive that no substantive differences exist despite sharp differences in the rules related to public statements around merger news in the U.S. and Germany. 


\section{REFERENCES}

Bhattacharya, Utpal and Hazem Daouk, 2002, "The World Price of Insider Trading," The Journal of Finance, 57, February, 75-108.

Boehmer, Ekkehart, 1999, “Corporate Governance in Germany: Institutional Background and Empirical Results,” working paper, Humboldt University Berlin, March. , 2000, "Business Groups, Bank Control, and Large Shareholders: An Analysis of German Takeovers," Journal of Financial Intermediation, 9, 117-148. 
Table 1

German Acquirer Firms

\begin{tabular}{|c|c|c|}
\hline Date & Acquirer & Target \\
\hline 19950619 & Mannesmann AG & Nuova Solmine SpA(Enirisorse) \\
\hline 19950109 & Deutsche Lufthansa AG & Air Dolomiti \\
\hline 19950112 & Siemens AG & Arche Communications \\
\hline 19950407 & Siemens AG & Amper Telematica,Amper Datos \\
\hline 19950408 & Siemens AG & Modern Engineering \& Consultan \\
\hline 19950611 & Siemens AG & ATM dd \\
\hline 19950707 & Bayerische Vereinsbank AG & Bank Rozwoju Energetyki \\
\hline 19950712 & Daimler-Benz AG & AEG Oesterreich(AEG AG) \\
\hline 19950812 & Hochtief AG(RWE AG) & KPIS-Cracovia SA \\
\hline 19950911 & Metallgesellschaft AG & Metallgesellschaft Ltd \\
\hline 19951002 & Bayerische Vereinsbank AG & Undisclosed Polish Banks(2) \\
\hline 19951205 & VIAG AG & Suedgas \\
\hline 19960102 & Siemens AG & Italtel Telematica \\
\hline 19960210 & Mannesmann AG & Omnitel Sistemi Radiocellulari \\
\hline 19960502 & Daimler-Benz AG & Mercedes-Benz Mexico(Daimler) \\
\hline 19960805 & VEBA AG & Rhone-Poulenc-Division \\
\hline 19960807 & Siemens AG & Elcaro SA \\
\hline 19961106 & Siemens AG & Geros-Kabel \\
\hline 19970509 & Mannesmann AG & Olivetti Mobile Telephone \\
\hline 19971010 & Hochtief AG(RWE AG) & Ballast Indonesia Construction \\
\hline 19971206 & Deutsche Lufthansa AG & Air Littoral \\
\hline 19980110 & Merck AG & Rohrbeck \\
\hline 19980204 & Volkswagen AG & Rolls-Royce Motor Cars Ltd \\
\hline 19980206 & Volkswagen AG & Same Lamborhini-Hurlimann \\
\hline 19980303 & Mannesmann AG & Tele.Ring \\
\hline 19980402 & Dresdner Bank AG & Kleinwort Benson Iberfomento \\
\hline 19980405 & Commerzbank AG & Security Capital Group Inc \\
\hline 19980511 & Daimler-Benz AG & Micro Compact Car AG \\
\hline 19980605 & Daimler-Benz AG & Chrysler Corp \\
\hline 19980608 & Allianz AG & Towarzystwo Ubezpieczeniowe \\
\hline 19980710 & Allianz AG & AGF Union-Fenix(Assurance Gen) \\
\hline 19980804 & Daimler-Benz AG & Eurostar \\
\hline 19980907 & Dresdner Bank AG & Credit Lyonnais-Swedish \\
\hline 19980910 & Daimler-Benz AG & Thomas Built Buses Inc \\
\hline 19980911 & Commerzbank AG & Assicurazioni Generali SpA \\
\hline 19981108 & Dresdner Bank AG & PaineWebber Group Inc \\
\hline 19981210 & Merck AG & Neuber GmbH-Laboratory \\
\hline 19990104 & Linde AG & Criosbanc SpA \\
\hline 19990206 & Allianz AG & Eagle Star President Life \\
\hline 19990312 & Siemens AG & CKD Praha Holdings \\
\hline 19990408 & Allianz AG & Shin Dong AH Fire \& Marine \\
\hline 19990502 & Bayer AG & DSM NV-Transparent Sheet Bus \\
\hline
\end{tabular}




\begin{tabular}{|c|c|}
\hline 19990502 & Commerzbank AG \\
\hline 19990503 & DaimlerChrysler AG \\
\hline 19990601 & Linde AG \\
\hline 19990610 & Allianz AG \\
\hline 19990712 & Commerzbank AG \\
\hline 19990806 & Merck AG \\
\hline 19990903 & Bayer AG \\
\hline 19990907 & DaimlerChrysler AG \\
\hline 19991102 & DaimlerChrysler AG \\
\hline 19991110 & Siemens AG \\
\hline 19991202 & Commerzbank AG \\
\hline 19991205 & Allianz AG \\
\hline 19991207 & Merck AG \\
\hline 1990608 & Deutsche Telekom AG \\
\hline 19950108 & Muenchener Rueckversicherungs \\
\hline 19950112 & Dresdner Bank AG \\
\hline 19950125 & Dresdner Bank AG \\
\hline 19950125 & VEBA AG \\
\hline 19950211 & Dresdner Bank AG \\
\hline 19950227 & BASF AG \\
\hline 19950227 & Gehe AG(Franz Haniel \& Cie) \\
\hline 19950228 & Hoechst AG \\
\hline 19950228 & Siemens AG \\
\hline 19950313 & Bayer AG \\
\hline 19950315 & Deutsche Bank AG \\
\hline 19950316 & Daimler-Benz AG \\
\hline 19950322 & Bilfinger \& Berger Bau AG \\
\hline 19950410 & RWE AG \\
\hline 19950410 & Allianz AG \\
\hline 19950413 & Siemens AG \\
\hline 19950414 & Daimler-Benz AG \\
\hline 19950421 & Bremer Vulkan AG \\
\hline 19950428 & Daimler-Benz AG \\
\hline 19950428 & Commerzbank AG \\
\hline 19950516 & Commerzbank AG \\
\hline 19950523 & Linde AG \\
\hline 19950531 & Bayerische Motoren Werke AG \\
\hline 19950531 & Linde AG \\
\hline 19950616 & Allianz AG \\
\hline 19950622 & Allianz AG \\
\hline 19950630 & VIAG AG \\
\hline 19950630 & Volkswagen AG \\
\hline 19950711 & Bayerische Vereinsbank AG \\
\hline 19950728 & Bayer AG \\
\hline 19950728 & Hochtief AG(RWE AG) \\
\hline 19950815 & MAN AG \\
\hline 19950829 & Bilfinger \& Berger Bau AG \\
\hline 19950830 & SGL Carbon AG(Hoechst AG) \\
\hline
\end{tabular}

KEB Investment Tr Mgmt Co Ltd Harry Karlsson Bilimport AB Airgas Inc-Polish Ind Gas Bus PIMCO Advisors Holdings LP INA

Apotec

PBI Home \& GardenLtd(Sumitomo)

Volvo AB

Thonburi Automobile Assembly

NeoPoint Inc

Majan International Bank

First Life Insurance Co Ltd

Silicon Valley Chemlabs Inc

One-2-One

Mercury Asset Management PLC

RCM Capital Mgmt(Travelers)

Kleinwort Benson Group PLC

Cable \& Wireless PLC

St Petersburg Govt-Grand Hotel

DuPont-Idemitsu(El du Pont)

AAH PLC

Marion Merrell Dow Inc

Jeil Hitech

Florasynth Inc

Societe Generale Surveillance

ABB Asea Brown Boveri-Worldwid

$B$ \& B Asia(Bilfinger \& Berger)

ENDESA(SEPI/Spain)

Hungaria Biztosito(Allianz AG)

Simko Ticaret ve Sanayi(Sieme)

Mercedes-Benz Italia SpA

Shanghai Edward Shipbuilding

Swissmetro AG

Capital Investment Trust Corp

Prima Property Trust Ltd

Technoplyn Prague AS(Linde AG)

Designworks/USA(Bayerische)

Linde Technoplyn(Linde AG)

Legal \& General Group PLC

Assurances Federales IARD

SBI Systems Bio-Industries SA

Dead Sea Works-Sodom Plant

Oppenheimer(Oppenheimer Group)

Agritech Saigon

POZ Building Ltd

Simac Spa

Baulderstone Hornibrook(AW)

Polgraph SA(Bank Handlowy SA) 


\begin{tabular}{|c|c|c|}
\hline 19950831 & Commerzbank AG & Hambros Bank Ltd(Hambros PLC) \\
\hline 19950902 & Bilfinger \& Berger Bau AG & Entreprise Razel Freres \\
\hline 19950914 & Bayerische Vereinsbank AG & MegaBank Financial \\
\hline 19950914 & Allianz AG & Riunione Adriatica di Securita \\
\hline 19950915 & Thyssen AG & PlusNET(MDS HIdg/Alcatel STR) \\
\hline 19950925 & Siemens AG & Ornet Data Commun Technologies \\
\hline 19950927 & Bayer AG & Myriad Genetics Inc \\
\hline 19950928 & Deutsche Bank AG & Finanza \& Futuro(Deutsche Bk) \\
\hline 19950928 & Allianz AG & Lloyd Adriatico SpA \\
\hline 19951002 & Hoechst AG & Caraplas Ltd-Production Rights \\
\hline 19951007 & Bayerische Hypotheken & Wielkopolski Bank Rolniczy \\
\hline 19951026 & Bremer Vulkan AG & ECA SARL \\
\hline 19951026 & Gehe AG(Franz Haniel \& Cie) & Laboratoires Gallier SA \\
\hline 19951030 & BHF Bank AG & TIR Holdings Ltd \\
\hline 19951114 & Bayer AG & Monsanto Co-Styrenics Plastics \\
\hline 19951115 & Daimler-Benz AG & Daimler-Benz Holding France \\
\hline 19951124 & BASF AG & Undisclosed Bulgarian Chemical \\
\hline 19951129 & Allianz AG & Manufacturers Mutual Insurance \\
\hline 19951207 & Bayer AG & Miles India Ltd \\
\hline 19951215 & Buderus AG & Tiroler Roehren-und \\
\hline 19951222 & Allianz AG & Duerrevita \\
\hline 19951229 & Hoechst AG & Grafitos Electricos \\
\hline 19951229 & RWE AG & Emasz(Hungary) \\
\hline 19951229 & Kaufhof AG & WestBTL Handel-Beteiligungs \\
\hline 19960107 & Hoechst AG & Polymer Color \\
\hline 19960119 & Linde AG & Praxair Inc-Linde Trademark \\
\hline 19960131 & Preussag AG & Elco Looser Holding AG \\
\hline 19960201 & Beiersdorf AG & Tyco Intl-Curad and Futuro \\
\hline 19960201 & Allianz AG & Feder 01 \\
\hline 19960213 & RWE AG & Tlakova Plyarna Usti \\
\hline 19960227 & Renk AG(MAN AG) & Renk Resita SA \\
\hline 19960315 & Degussa AG & Muro Pharmaceuticals Inc \\
\hline 19960326 & Allianz AG & Berner Holding AG \\
\hline 19960327 & Merck AG & Seven Seas Ltd(Hanson PLC) \\
\hline 19960407 & Bayer AG & Sclavo SpA-Siena-Bellaria Unit \\
\hline 19960410 & Commerzbank AG & Eurocorp International Finance \\
\hline 19960502 & Hoechst AG & SGL Technic(SGL Carbon/Hoesch) \\
\hline 19960509 & Allianz AG & Allianz-Ultramar \\
\hline 19960515 & Preussag AG & Albania-Chrome Industry \\
\hline 19960517 & Hoechst AG & Plastics Materials Company Inc \\
\hline 19960517 & Siemens AG & Amper Telematica,Amper Datos \\
\hline 19960524 & Commerzbank AG & Security Capital Group Inc \\
\hline 19960614 & Commerzbank AG & Wood \& Co \\
\hline 19960618 & Merck AG & Willi Fisher oHG \\
\hline 19960716 & Schering AG & Leiras(Huhtamaki Oy) \\
\hline 19960731 & Hoechst AG & Hoechst Marion Roussel Ltd \\
\hline 19960805 & BASF AG & Zeneca Textile Color(ZENECA) \\
\hline 19960814 & Muenchener Rueckversicherungs & American Re Corp \\
\hline
\end{tabular}




\begin{tabular}{|c|c|}
\hline 19960908 & SAP AG \\
\hline 19960910 & Siemens AG \\
\hline 19960916 & Bayer AG \\
\hline 19960917 & Deutsche Bank AG \\
\hline 19960920 & Siemens AG \\
\hline 19960926 & Mannesmann AG \\
\hline 19960927 & BASF AG \\
\hline 19961012 & Hoechst AG \\
\hline 19961014 & Deutsche Bank AG \\
\hline 19961114 & Bayerische Hypotheken \\
\hline 19961121 & Allianz AG \\
\hline 19961207 & Mannesmann AG \\
\hline 19961219 & Deutsche Bank AG \\
\hline 19961223 & Siemens AG \\
\hline 19970109 & Daimler-Benz AG \\
\hline 19970112 & Merck AG \\
\hline 19970120 & Degussa AG \\
\hline 19970124 & Allianz AG \\
\hline 19970130 & Hoechst AG \\
\hline 19970131 & Dresdner Bank AG \\
\hline 19970131 & Siemens AG \\
\hline 19970205 & Deutsche Bank AG \\
\hline 19970217 & Deutsche Bank AG \\
\hline 19970219 & Commerzbank AG \\
\hline 19970314 & Metro AG \\
\hline 19970317 & Mannesmann AG \\
\hline 19970317 & Siemens AG \\
\hline 19970319 & Merck AG \\
\hline 19970324 & Linde AG \\
\hline 19970324 & Preussag AG \\
\hline 19970326 & Commerzbank AG \\
\hline 19970404 & Degussa AG \\
\hline 19970414 & Daimler-Benz AG \\
\hline 19970430 & BASF AG \\
\hline 19970430 & Metallgesellschaft AG \\
\hline 19970526 & Siemens AG \\
\hline 19970624 & Daimler-Benz AG \\
\hline 19970718 & Metro AG \\
\hline 19970723 & SGL Carbon AG(Hoechst AG) \\
\hline 19970731 & Degussa AG \\
\hline 19970801 & Bayer AG \\
\hline 19970808 & Siemens AG \\
\hline 19970814 & VIAG AG \\
\hline 19970814 & Commerzbank AG \\
\hline 19970820 & Bayer AG \\
\hline 19970827 & Deutsche Telekom AG \\
\hline 19970904 & Siemens AG \\
\hline 19970905 & BASF AG \\
\hline
\end{tabular}

IntelliCorp

Ingelsar Ingeneria Electrica

Chiron Diagnostics Corp

21 Investimenti(Edizione HIdg)

Fuji Electric Components(Fuji)

CEGETEL(Generale des Eaux)

Sandoz AG-US and Canada Corn

Roussel-Uclaf SA(Hoechst AG)

Princess Resources Ltd

Foreign \& Colonial Mgmt Ltd

Manufacturers Mutual Insurance

Italimpianti-Steel Engineering

Irmaos Guimaraes(Banco Irmaos)

Elektrowatt AG

Micro Compact Car AG

Kemifarma

Carbochem(Poland)

Fichet-Bauche SA

Plastocoat Srl

SES ASTRA SA

Broadband Networks Inc

Axiom Funds Management Corp

Xavier Corp

Montgomery Asset Management

Vobis Microcomputer(Metro AG)

United Steel Mills(Koor Inds)

Siemens South Africa(Siemens)

Merck Generics BV(Merck E)

Jihostroj Velesin-Cesky

Chaffoteaux et Maury(Elfi SA)

Montgomery Securities-Money

Agrolinz Melamin Italia Srl-

Ballard Power Systems Inc

Dow Benelux NV-Engine Coolant

Cerro Sales Corp

Hydraulik-Ring Beteiligungs

Meris \& Cie SA

Makro Holdings-European

Hitco Technologies

El du Pont-Worldwide Hydrogen

Central Polimeros da Bahia SA

Siemens Automotive Systems

Finesca SA

Bank Rozwoju Eksportu

Bayer Premier Co Ltd(Bayer AG)

Ing C Olivetti \& Co SpA

Parsons Power Generation Sys

Kutnowskie Zaklady-Veterinary 


\begin{tabular}{|c|c|}
\hline 19970905 & Porsche AG \\
\hline 19970907 & Linde AG \\
\hline 19970912 & BASF AG \\
\hline 19970916 & Adidas AG \\
\hline 19970916 & Degussa AG \\
\hline 19970916 & Muenchener Rueckversicherungs \\
\hline 19970922 & Douglas Holding AG \\
\hline 19970923 & Muenchener Rueckversicherungs \\
\hline 19970930 & Thyssen AG \\
\hline 19971003 & Commerzbank AG \\
\hline 19971113 & Siemens AG \\
\hline 19971117 & Allianz AG \\
\hline 19971206 & Thyssen AG \\
\hline 19971217 & Bayerische Vereinsbank AG \\
\hline 19971231 & Daimler-Benz AG \\
\hline 19971510 & Siemens AG \\
\hline 19980104 & Fresenius Medical Care AG \\
\hline 19980110 & Volkswagen AG \\
\hline 19980113 & Deutsche Bank AG \\
\hline 19980130 & Preussag AG \\
\hline 19980210 & Siemens AG \\
\hline 19980213 & Degussa AG \\
\hline 19980217 & Allianz AG \\
\hline 19980226 & Metro AG \\
\hline 19980304 & BASF AG \\
\hline 19980304 & Bayer AG \\
\hline 19980318 & BASF AG \\
\hline 19980318 & MobilCom AG \\
\hline 19980323 & Siemens AG \\
\hline 19980326 & Merck AG \\
\hline 19980330 & Bayerische Motoren Werke AG \\
\hline 19980330 & Bayerische Vereinsbank AG \\
\hline 19980406 & Deutsche Telekom AG \\
\hline 19980409 & Hoechst AG \\
\hline 19980421 & Linde AG \\
\hline 19980423 & SAP AG \\
\hline 19980423 & Metro AG \\
\hline 19980428 & Mannesmann AG \\
\hline 19980518 & Gehe AG(Franz Haniel \& Cie) \\
\hline 19980520 & Daimler-Benz AG \\
\hline 19980618 & Volkswagen AG \\
\hline 19980629 & Degussa AG \\
\hline 19980629 & Thyssen AG \\
\hline 19980630 & Siemens AG \\
\hline 19980701 & BASF AG \\
\hline 19980710 & Bayerische Vereinsbank AG \\
\hline 19980720 & Deutsche Telekom AG \\
\hline 19980721 & BASF AG \\
\hline
\end{tabular}

Porsche Italia SpA(Porsche AG)

Radford Retail Systems(Wagon)

Hanwha BASF Urethane

Salomon SA

Ney Dental International Inc

Syndicate 457 Capital Ltd

Sephora(LVMH Moet Hennessy)

Reale Riassicurazioni

Electrodinox

Banque Marocaine du Commerce

Westinghouse-Conven Power Gen

AGF

Giddings \& Lewis Inc

FGH Hypotheekbank NV(Aegon)

Micro Compact Car France

Breed Technologies Inc

Tek Systems Inc

Autoeuropa Automoveis Lda

EL\&C Baillieu Ltd

Palette Rouge

Matra Transport International

Qingdao Degussa Chemical Co

National Ins Co of Brunei

Allkauf SB-Warenhaus $\mathrm{GmbH}$ and

Clariant AG-Superabsorber Bus

W Hawley \& Son-Pigment Bus

Daesung Corp-Lysine Unit

Cellway(Martin Dawes)

Cegielski SA(Poland)

Pharmaceutical Resources Inc

Rolls-Royce Motor Cars Ltd

Banco Popular Espanol SA

Isla Communications(Asiacom)

Handok Pharmaceuticals

Serai do Brasil SA

ILOG SA

Kaufhalle AG(Kaufhof AG)

Citykom

Office Coml Pharmaceutique

Nissan Diesel Motor Co Ltd

Bugatti Automobili

Silquimica SA(Degussa/Genaral)

Comercial de Aceros Heva SA

Elektro MAR

Schon Trykfarver A/S-Printing

Bank Przemyslowo-Handlowy SA

France Telecom SA(France)

Ciba Speciality Chem-Chelates 


\begin{tabular}{|c|c|}
\hline 19980722 & Allianz AG \\
\hline 19980730 & Siemens AG \\
\hline 19980731 & Metro AG \\
\hline 19980801 & Dresdner Bank AG \\
\hline 19980807 & Deutsche Bank AG \\
\hline 19980824 & Hannover Rueckversicherungs \\
\hline 19980917 & Metro AG \\
\hline 19980918 & Mannesmann AG \\
\hline 19980924 & Deutsche Bank AG \\
\hline 19980924 & Bayer AG \\
\hline 19981002 & MAN AG \\
\hline 19981013 & Deutsche Bank AG \\
\hline 19981016 & Bayer AG \\
\hline 19981020 & BASF AG \\
\hline 19981023 & Degussa AG \\
\hline 19981029 & Hoechst AG \\
\hline 19981029 & Linde AG \\
\hline 19981030 & Degussa AG \\
\hline 19981030 & Metro AG \\
\hline 19981030 & Allianz AG \\
\hline 19981109 & Hoechst AG \\
\hline 19981116 & Linde AG \\
\hline 19981117 & VIAG AG \\
\hline 19981117 & Allianz AG \\
\hline 19981120 & Degussa AG \\
\hline 19981126 & Siemens AG \\
\hline 19981127 & BASF AG \\
\hline 19981130 & Deutsche Bank AG \\
\hline 19981201 & Bayer AG \\
\hline 19981210 & Degussa AG \\
\hline 19981216 & BASF AG \\
\hline 19981216 & Merck AG \\
\hline 19981221 & Allianz AG \\
\hline 19981223 & BASF AG \\
\hline 19981223 & Preussag AG \\
\hline 19981223 & Siemens AG \\
\hline 19990112 & BASF AG \\
\hline 19990118 & BASF AG \\
\hline 19990128 & Siemens AG \\
\hline 19990219 & Deutsche Telekom AG \\
\hline 19990219 & Mannesmann AG \\
\hline 19990222 & Commerzbank AG \\
\hline 19990226 & Degussa AG \\
\hline 19990303 & Schering AG \\
\hline 19990308 & Siemens AG \\
\hline 19990311 & Metro AG \\
\hline 19990315 & Deutsche Telekom AG \\
\hline 19990318 & Siemens AG \\
\hline
\end{tabular}

Adriatic Osiguranje Original Electromechanical Grp Emil Kriegbaum $\mathrm{GmbH}$ und Co KG Sopockie Towarzystwo Credit Lyonnais Belgium Clarendon America Insurance Co Importgesellschaft Gemex Olivetti Mobile Telephone Banca Commerciale Italiana SpA Millennium Pharmaceuticals Inc SEMT Pielstick(Daiml-Benz,Man) Boullioun Aviation Services Haldia Petrochemicals DSM NV-ABS Business Insilco Ltd Rhone-Poulence Ltd. Gephal SA Ceramic Materials(Philips) Vorteilkauf V-Stores(14) MMI Ltd(Allianz AG) Hoechst South Africa Ltd Millenium Petrochemicals-Int Alusuisse Lonza Group Ltd Bulgaria Holdings LG Chemical Co Ltd-Carbon Amper Elasa SA(Siemens AG) Dongsong Chem-Plastic Plant Bankers Trust New York Corp Canvet Ltd

Solquimica Quadrant Holding Lexigen Pharmaceuticals Corp AGF Irish Life Corp Dong Seong-Polyurethane Op Thomas Cook Group Ltd Courbon SA Sunsmart Inc-Zinc Oxide Bus Svalof Weibull AB Itron max.mobil.Telekommunikation Ing C Olivetti-Telecom Int ADIG Investment Luxemburg SA Fermal Sro Aventis Crop Science Italtel-Mobile Network Der Praktiker Bau und Isla Communications(Asiacom) RedStone Communications Inc 


\begin{tabular}{|c|c|}
\hline 19990319 & Bayer AG \\
\hline 19990331 & Deutsche Lufthansa AG \\
\hline 19990402 & Deutsche Bank AG \\
\hline 9990403 & EM.TV \& Merchandising AG \\
\hline 19990410 & Deutsche Telekom AG \\
\hline 19990419 & Deutsche Telekom AG \\
\hline 19990429 & Commerzbank AG \\
\hline 19990503 & Siemens AG \\
\hline 19990510 & Deutsche Bank AG \\
\hline 19990511 & Deutsche Bank AG \\
\hline 19990517 & Deutsche Telekom AG \\
\hline 19990518 & Siemens AG \\
\hline 19990518 & Commerzbank AG \\
\hline 19990519 & Hoechst AG \\
\hline 19990528 & Deutsche Bank AG \\
\hline 19990601 & Deutsche Bank AG \\
\hline 19990604 & BASF AG \\
\hline 19990614 & Commerzbank AG \\
\hline 19990625 & Siemens AG \\
\hline 19990716 & Fresenius Medical Care AG \\
\hline 19990723 & Allianz AG \\
\hline 19990726 & Fresenius Medical Care AG \\
\hline 19990730 & Kinowelt Medien AG \\
\hline 19990730 & Linde AG \\
\hline 19990806 & Deutsche Bank AG \\
\hline 19990813 & Linde AG \\
\hline 19990830 & Continental AG \\
\hline 19990831 & Siemens AG \\
\hline 19990911 & Deutsche Lufthansa AG \\
\hline 19990913 & Dresdner Bank AG \\
\hline 19990915 & Aixtron AG \\
\hline 19990917 & Commerzbank AG \\
\hline 19990922 & Deutsche Lufthansa AG \\
\hline 19991008 & Aixtron AG \\
\hline 19991015 & DaimlerChrysler AG \\
\hline 19991019 & Mannesmann AG \\
\hline 19991021 & Allianz AG \\
\hline 19991022 & Deutsche Telekom AG \\
\hline 19991025 & Deutsche Bank AG \\
\hline 19991028 & RWE AG \\
\hline 19991029 & Allianz AG \\
\hline 19991116 & Dresdner Bank AG \\
\hline 19991116 & Bayer AG \\
\hline 19991117 & Deutsche Telekom AG \\
\hline 19991118 & BASF AG \\
\hline 19991126 & Volkswagen AG \\
\hline 19991204 & Deutsche Bank AG \\
\hline 19991205 & Deutsche Bank AG \\
\hline
\end{tabular}

Bayer Sankyo Co

$\mathrm{SH} \& \mathrm{E}$

Newcourt Credit Group USA Inc

Yoram Gross Film Studios Pty

Hrvatske Telekomunikacije $\{\mathrm{HT}\}$

Telecom Italia SpA

Argor-Heraeus SA(WC Heraeus)

Castle Networks

Bank Wspolpracy Regionalnej SA

Alkaloid

Polska Telefonia Cyfrowa Sp

Elsag Bailey-Gas Chromatograph

Banco Santander Central Hispan

Celanese Canada Inc

Orbis SA

Unicredito Italiano

BP Amoco-Global Polyethylene

Credit Lyonnais SA(France)

Phone.com Inc

St John Dialysis Network

Berner Versicherung

Kolon Pharmaceutical Inc-Dialy

Alliance Atlantis Comm Inc

ABC Synergie SA

Ergobank SA

AGA AB

Moscow Tire Works

Yaskawa System Engineering

British Midland Airways Ltd

Ernst \& Young Trust Co

Thomas Swan \& Co-Scientific

Bank Handlowy SA

Air Dolomiti

Epigress $A B$

Ssang Yong Motor-Van Division

Orange PLC

Zagrebacka Banka

Russian Telecommunications

Chase-Dutch Auction Bus

Emasz(RWE AG)

PIMCO Advisors LP

Ad Gestioni Sgr

Lyondell Chemical-Polyils Bus

SIRIS SAS(Unisource,CGE)

BASF-Suemerbank Tuerk Sanayii

Europcar International SA

BIG Bank Gdanski SA

TransAtlantic Capital Co LLC 
19991215 Muenchener Rueckversicherungs 19991216 SAP AG

19991217 Siemens AG

19991221 BASF AG

19991412 ConSors Discount Broker AG

19999510 EM.TV \& Merchandising AG
Orel ID2(LM Ericsson Telefon AB)

CKD Dopravni Systemy

Morton Industrial Coatings

Siaga

Plus Licens AB 
Table 2

\section{U.S. Acquirer Firms}

\begin{tabular}{|c|c|c|}
\hline Date & Acquirer & Target \\
\hline 19960118 & Pfizer Inc & Corvita Corp \\
\hline 19960201 & Walt Disney Co & Jumbo Pictures \\
\hline 19960205 & Eastman Kodak Co Inc & Eckerd Corp-Photo-Processing \\
\hline 19960212 & EMC Corp & MTI Tech-Patent Portfolio \\
\hline 19960222 & Hewlett-Packard Co & SecureWare-Internet SystemSec \\
\hline 19960227 & Hewlett-Packard Co & Business@Web Inc \\
\hline 19960227 & BankAmerica Corp & FBS Mortgage Corp \\
\hline 19960326 & Pfizer Inc & Microcide Pharmaceuticals \\
\hline 19960401 & Automatic Data Processing Inc & Merrin Financial Inc \\
\hline 19960401 & SBC Communications Inc & Pacific Telesis Group \\
\hline 19960415 & Automatic Data Processing Inc & Information Catalysts Inc \\
\hline 19960418 & Walt Disney Co & Dream Quest Images \\
\hline 19960418 & Bristol-Myers Squibb Co & Somatix Therapy Corp \\
\hline 19960423 & Walt Disney Co & Walt Disney Co \\
\hline 19960506 & Procter \& Gamble Co & Eagle Snacks Inc \\
\hline 19960506 & Winn-Dixie Stores Inc & Xtra Super Food-Dade County(2) \\
\hline 19960508 & Pfizer Inc & Catalytica Fine Chemicals \\
\hline 19960515 & Tyco International Ltd & Carlisle Plastics Inc \\
\hline 19960523 & Procter \& Gamble Co & Kimberly-Clark-4 Businesses \\
\hline 19960610 & Pfizer Inc & Vesta Medical Inc \\
\hline 19960612 & Praxair Inc & Bakersfield Welding,Gerin \\
\hline 19960613 & Berkshire Hathaway Inc & Sears Roebuck \& Co \\
\hline 19960620 & Tyco International Ltd & Henry Pratt Co,James JonesCo \\
\hline 19960725 & Praxair Inc & Bob Smith,Jay-Ox,B\&E Welding \\
\hline 19960726 & BankAmerica Corp & Ford Motor Credit Co \\
\hline 19960801 & GTE Corp & GTE Corp \\
\hline 19960801 & Boeing Co & Rockwell Intl Corp-Aerospace \\
\hline 19960805 & Bristol-Myers Squibb Co & Oncology Therapeutics Network \\
\hline 19960805 & Hewlett-Packard Co & Trellis Software \& Controls \\
\hline 19960812 & SBC Communications Inc & AT\&T Wireless-AR CellularPpty \\
\hline 19960814 & General Mills Inc & Ralcorp HIdgs-Branded Cereal \\
\hline 19960815 & Walt Disney Co & Cinergi Pictures Entertainment \\
\hline 19960816 & Automatic Data Processing Inc & Staff Mgmt Systems of Florida \\
\hline 19960819 & Bristol-Myers Squibb Co & Envision Medical Corp \\
\hline 19960924 & Automatic Data Processing Inc & Global Proxy-Processing Bus \\
\hline 19960930 & SBC Communications Inc & HighwayMaster Communications \\
\hline 19961003 & Eastman Kodak Co Inc & Wang Labs-Imaging Software \\
\hline 19961008 & Lucent Technologies Inc & Agile Networks \\
\hline 19961015 & Berkshire Hathaway Inc & FlightSafety International \\
\hline 19961114 & Tyco International Ltd & TJ Cope \\
\hline 19961121 & Johnson \& Johnson & Bausch \& Lomb Inc \\
\hline
\end{tabular}




\begin{tabular}{|c|c|c|}
\hline 19961129 & Tyco International Ltd & ElectroStar Inc \\
\hline 19961202 & PepsiCo Inc & Quaker Oats Co-Gatorade \\
\hline 19961219 & Automatic Data Processing Inc & HealthPlan Services Corp \\
\hline 19970110 & Tyco International Ltd & American Standard Companies \\
\hline 19970116 & Home Depot Inc & Maintenance Warehouse/America \\
\hline 19970116 & Home Depot Inc & Maintenance Warehouse/America \\
\hline 19970120 & Target Therapeutics Inc & Boston Scientific Corp \\
\hline 19970124 & Tyco International Ltd & Sempell Valve Group \\
\hline 19970124 & KPDX-TV,KFXO-TV,WHNS-TV & Meredith Corp \\
\hline 19970124 & Community Care of America Inc & Integrated Health Services Inc \\
\hline 19970203 & Eastman Kodak Co Inc & Nova Microsonics \\
\hline 19970203 & Eastman Kodak Co Inc & Nova Microsonics \\
\hline 19970205 & Tyco International Ltd & American Tube \& Pipe Co \\
\hline 19970214 & Walt Disney Co & Starwave Corp \\
\hline 19970214 & Oppenheimer Capital LP & Thomson Advisory Group LP \\
\hline 19970218 & El du Pont de Nemours and Co & Pfister Hybrid Corn Co \\
\hline 19970218 & Invetech Co & Applied Industrial Tech \\
\hline 19970219 & Hewlett-Packard Co & Symantec Corp-Networking Busn \\
\hline 19970224 & Walt Disney Co & Pixar Animation Studio \\
\hline 19970310 & General Electric Co & Greenwich Air Services Inc \\
\hline 19970401 & General Electric Co & ICS Holdings Inc \\
\hline 19970409 & Eli Lilly \& Co & Seragen Inc(Boston University) \\
\hline 19970411 & Tyco International Ltd & AT\&T Submarine Systems Inc \\
\hline 19970418 & Vitalink Pharmacy Services Inc & Manor Care Inc \\
\hline 19970423 & Hewlett-Packard Co & VeriFone Inc \\
\hline 19970428 & Abbott Laboratories & Sanofi Pharmaceuticals - Parente \\
\hline 19970429 & Boeing Co & Teledesic LLC \\
\hline 19970506 & GTE Corp & BBN Corp \\
\hline 19970509 & Chase Manhattan Corp,NY & Compass Bk,AL-Corporate Tr Bus \\
\hline 19970512 & Homestead Village Inc & Security Capital Group Inc \\
\hline 19970513 & Tyco International Ltd & Inbrand Corp \\
\hline 19970520 & Tyco International Ltd & Keystone International Inc \\
\hline 19970527 & Coca-Cola Enter(Coca-Cola Co) & Coca-Cola Bottling Co of NY \\
\hline 19970527 & Walt Disney Co & International Family Ent Inc \\
\hline 19970527 & AT\&T Corp & SBC Communications Inc \\
\hline 19970529 & Eli Lilly \& Co & Millennium BioTherapeutics Inc \\
\hline 19970604 & Hewlett-Packard Co & Iomega Corp \\
\hline 19970609 & BankAmerica Corp & Robertson Stephens \& Co \\
\hline 19970612 & Eastman Kodak Co Inc & Applied Network Solutions Inc \\
\hline 19970612 & Eastman Kodak Co Inc & Applied Network Solutions Inc \\
\hline 19970612 & First of Michigan Capital Corp & Fahnestock Viner Holdings Inc \\
\hline 19970617 & Berkshire Hathaway Inc & Natl Health Laboratories Inc \\
\hline 19970624 & Berkshire Hathaway Inc & Star Furniture Co \\
\hline 19970627 & Northwest Bancshares,Louisiana & Hibernia Corp,New Orleans,LA \\
\hline 19970717 & Lucent Technologies Inc & Octel Communications Corp \\
\hline 19970718 & Sprint Corp & Paranet Inc \\
\hline 19970721 & Walt Disney Co & Mammoth Records \\
\hline 19970723 & Eastman Kodak Co Inc & Picture Network Intl Inc \\
\hline
\end{tabular}




\begin{tabular}{|c|c|c|}
\hline 19970723 & Eastman Kodak Co Inc & Picture Network Intl Inc \\
\hline 19970725 & General Electric Co & Liberty Tech-Nondestructive \\
\hline 19970807 & El du Pont de Nemours and Co & Pioneer Hi-Bred International \\
\hline 19970819 & Ford Motor Co & Toledo Molding \& Die Inc \\
\hline 19970821 & El du Pont de Nemours and Co & Protein Technologies Intl \\
\hline 19970916 & Praxair Inc & Gas Tech Inc \\
\hline 19970918 & Stokely USA Inc & Chiquita Brands International \\
\hline 19970919 & CBS Corp & American Radio Systems Corp \\
\hline 19970923 & AT\&T Corp & E-Stamp Corp \\
\hline 19971008 & BankAmerica Corp & Home Properties of New York \\
\hline 19971015 & Lucent Technologies Inc & Livingston Enterprises \\
\hline 19971015 & GTE Corp & $\mathrm{MCl}$ Communications Corp \\
\hline 19971021 & Chase Manhattan Corp, $\mathrm{NY}$ & Bank of New York-Credit Card \\
\hline 19971021 & Berkshire Hathaway Inc & International Dairy Queen Inc \\
\hline 19971031 & El du Pont de Nemours and Co & Westrade USA Inc \\
\hline 19971107 & Tyco International Ltd & Jason Marketing Corp \\
\hline 19971124 & Home Depot Inc & Deekay Enterprises Inc \\
\hline 19971201 & EMC Corp & Sutmyn Storage Corp \\
\hline 19971208 & General Motors Corp & Republic Industries-Saturn(6) \\
\hline 19971210 & Lucent Technologies Inc & Prominet Corp \\
\hline 19971215 & General Electric Co & Cal Tech Controls \\
\hline 19971219 & Chevron Corp & Chevron Corp \\
\hline 19971222 & American International Group & American Bankers Ins Group Inc \\
\hline 19971222 & Tyco International Ltd & Sherwood-Davis \& Geck \\
\hline 19971229 & Tyco International Ltd & Holmes Protection Group Inc \\
\hline 19971229 & Holmes Protection Group Inc & Tyco International Ltd \\
\hline 19980105 & General Electric Co & Marketing Services Group Inc \\
\hline 19980105 & SBC Communications Inc & Southern New England Telecomm \\
\hline 19980108 & AT\&T Corp & Teleport Communications Group \\
\hline 19980121 & General Electric Co & Lockheed Martin-Bus Units(2) \\
\hline 19980123 & General Electric Co & GE Capital IT Solutions \\
\hline 19980126 & Automatic Data Processing Inc & MICA Accounting Software \\
\hline 19980127 & Bristol-Myers Squibb Co & Redmond Products Inc \\
\hline 19980204 & Walt Disney Co & Starwave Corp \\
\hline 19980211 & IBM Corp & Commquest Technologies Inc \\
\hline 19980211 & Sprint Corp & EarthLink Network Inc \\
\hline 19980212 & Eastman Kodak Co Inc & PictureVision \\
\hline 19980212 & Eastman Kodak Co Inc & PictureVision \\
\hline 19980217 & Hewlett-Packard Co & MTI Analytical Instruments \\
\hline 19980313 & IBM Corp & Chem Systems Group Inc \\
\hline 19980318 & Chase Manhattan Corp,NY & Merrill Lynch \& Co Inc \\
\hline 19980406 & Coca-Cola Enter(Coca-Cola Co) & Coca-Cola Bottling,TexasBottl \\
\hline 19980417 & Tyco International Ltd & Borg-Wells Fargo Alarm Bus \\
\hline 19980424 & General Motors Corp & Millender Center,Detroit,MI \\
\hline 19980427 & Lucent Technologies Inc & Yurie Systems Inc \\
\hline 19980428 & American International Group & American Express Co \\
\hline 19980428 & American International Group & American Express Co \\
\hline 19980430 & Chase Manhattan Corp, NY & Marine Midland Bk-Continental \\
\hline
\end{tabular}




\begin{tabular}{|c|c|c|}
\hline 19980505 & GTE Corp & Virginia Cellular LP \\
\hline 19980507 & Chase Manhattan Corp, NY & Morgan Stanley Trust Co \\
\hline 19980511 & SBC Communications Inc & Ameritech Corp \\
\hline 19980525 & Tyco InternationalLtd & US Surgical Corp \\
\hline 19980527 & GTE Corp & Puerto Rico Telephone Co \\
\hline 19980528 & CBS Corp & KMJZ-FM,KSGS-AM,Minneapolis \\
\hline 19980528 & CBS Corp & WHOK-FM,WLVQ-FM,WAZU-FM \\
\hline 19980602 & Tyco International Ltd & Sigma Circuits Inc \\
\hline 19980608 & Tyco InternationalLtd & Crosby Valve(FMC Corp) \\
\hline 19980617 & AT\&T Corp & America Online Inc \\
\hline 19980618 & Walt Disney Co & Infoseek Corp \\
\hline 19980619 & Berkshire Hathaway Inc & General Re Corp \\
\hline 19980624 & Johnson \& Johnson & Amgen Inc \\
\hline 19980624 & AT\&T Corp & Tele-Communications Inc \\
\hline 19980630 & Sprint Corp & Cox Communications PCS LP \\
\hline 19980719 & American International Group & Transatlantic Holdings Inc \\
\hline 19980720 & PepsiCo Inc & Tropicana Products Inc \\
\hline 19980721 & Coca-Cola Enter(Coca-Cola Co) & Great Plains Bottler \& Canners \\
\hline 19980721 & Coca-Cola Enter(Coca-Cola Co) & Great Plains Bottler \& Canners \\
\hline 19980721 & General Electric Co & Raytheon Systems Ltd Flight \\
\hline 19980723 & AT\&T Corp & AT\&T Corp \\
\hline 19980723 & Berkshire Hathaway Inc & Executive Jet Inc \\
\hline 19980803 & Eastman Kodak Co Inc & Imation-Medical ImagingBus \\
\hline 19980804 & Abbott Laboratories & I-Stat Corp \\
\hline 19980804 & Chase Manhattan Corp, NY & PNC-Corp Trust and Escrow Bus \\
\hline 19980810 & EMC Corp & Conley Corp \\
\hline 19980812 & Boeing Co & Ellipso Inc \\
\hline 19980813 & CBS Corp & WYUU-FM,WLLD-FM,Tampa,Florida \\
\hline 19980817 & PepsiCo Inc & Pepsi-Cola Bottling Co \\
\hline 19980820 & American International Group & SunAmerica Inc \\
\hline 19980831 & IBP Inc & Diversified Food Corp-Appetize \\
\hline 19980922 & Tyco International Ltd & Sigma Circuits Inc \\
\hline 19981005 & AT\&T Corp & Vanguard Cellular Systems Inc \\
\hline 19981014 & Sprint Corp & PrimeCo-Hawaii PCS License \\
\hline 19981014 & PepsiCo Inc & Whitman Corp \\
\hline 19981020 & SBC Communications Inc & Concentric Network Corp \\
\hline 19981020 & Hewlett-Packard Co & Scope Communications Inc \\
\hline 19981021 & Coca-Cola Enter(Coca-Cola Co) & Independent Bottling Cos-6 \\
\hline 19981026 & Coca-Cola Enter(Coca-Cola Co) & Coca-Cola,Dr Pepper Bottling \\
\hline 19981026 & Coca-Cola Enter(Coca-Cola Co) & Coca-Cola,Dr Pepper Bottling \\
\hline 19981027 & El du Pont de Nemours and Co & Qualicon LLC \\
\hline 19981027 & IBM Corp & Wallop Software Inc-BUILD-IT \\
\hline 19981028 & AT\&T Corp & Arris Interactive-Cable System \\
\hline 19981028 & AT\&T Corp & Arris Interactive-Cable System \\
\hline 19981123 & Tyco International Ltd & AMP Inc \\
\hline 19981203 & Automatic Data Processing Inc & Vincam Group Inc \\
\hline 19981208 & AT\&T Corp & IBM Corp-Global Network Op \\
\hline 19990108 & AT\&T Corp & AT\&T Corp \\
\hline
\end{tabular}




\begin{tabular}{|c|c|c|}
\hline 19990111 & Lucent Technologies Inc & Kenan Systems Corp \\
\hline 19990113 & Walt Disney Co & Golden Books Family Ent \\
\hline 19990118 & General Mills Inc & Lloyd's Barbeque(Main Street) \\
\hline 19990119 & General Mills Inc & Farmhouse Foods Co \\
\hline 19990119 & AT\&T Corp & SmarTalk TeleServices Inc \\
\hline 19990119 & Ford Motor Co & Troy Design and Manufacturing \\
\hline 19990125 & Praxair Inc & GP Industries-Health Care Bus \\
\hline 19990125 & PepsiCo Inc & Whitman-WV,VA,Russia Ops \\
\hline 19990212 & Citigroup Inc & Oregon Steel Mills Inc \\
\hline 19990212 & Citigroup Inc & Reynolds Metals Co \\
\hline 19990310 & IBP Inc & H\&M Food Systems Co (Beledia) \\
\hline 19990317 & General Electric Co & Advanced Lighting Technologies \\
\hline 19990318 & Ford Motor Co & Zebra Imaging \\
\hline 19990326 & Citigroup Inc & Source One Mtg-Op Assets \\
\hline 19990401 & CBS Corp & King World Productions Inc \\
\hline 19990405 & GTE Corp & Ameritech Corp-Midwest Prop \\
\hline 19990405 & Lucent Technologies Inc & Mosaix Inc \\
\hline 19990407 & IBP Inc & Thorn Apple Valley Inc \\
\hline 19990409 & AT\&T Corp & Honolulu Cellular Telephone Co \\
\hline 19990409 & IBP Inc & Russer Foods \\
\hline 19990409 & Hewlett-Packard Co & Telegra Corp \\
\hline 19990412 & Tyco International Ltd & Batts Inc(Batts Group Ltd Inc) \\
\hline 19990412 & CBS Corp & Hollywood Online (Times Mirror) \\
\hline 19990412 & Sprint Corp & People's Choice TV Corp \\
\hline 19990414 & AT\&T Corp & Dobson Communications Corp \\
\hline 19990414 & AT\&T Corp & Dobson Communications Corp \\
\hline 19990416 & General Electric Co & ValueVision International Inc \\
\hline 19990420 & American International Group & John McStay Investment Counsel \\
\hline 19990422 & AT\&T Corp & MediaOne Group Inc \\
\hline 19990422 & CBS Corp & Office.com \\
\hline 19990423 & Sprint Corp & Cox Communications PCS LP \\
\hline 19990427 & Sprint Corp & American Telecasting \\
\hline 19990429 & CBS Corp & KEYE-TV, Austin, Texas \\
\hline 19990503 & Hewlett-Packard Co & Transoft Networks Inc \\
\hline 19990503 & Sprint Corp & Transworld Telecommunications \\
\hline 19990504 & AT\&T Corp & Lenfest Communications Inc \\
\hline 19990504 & AT\&T Corp & Lenfest Communications Inc \\
\hline 19990508 & Chevron Corp & Texaco Inc \\
\hline 19990511 & Automatic Data Processing Inc & Dealer Solutions Inc \\
\hline 19990511 & Automatic Data Processing Inc & Dealer Solutions Inc \\
\hline 19990519 & Tyco InternationalLtd & Raychem Corp \\
\hline 19990601 & Automatic Data Processing Inc & OMR Systems Corp \\
\hline 19990602 & CBS Corp & Switchboard Inc \\
\hline 19990603 & Home Depot Inc & Georgia Lighting \\
\hline 19990603 & Abbott Laboratories & Triangle Pharmaceuticals Inc \\
\hline 19990609 & Ford Motor Co & Automobile Protection Corp \\
\hline 19990609 & Ford Motor Co & Automobile Protection Corp \\
\hline 19990616 & Tyco International Ltd & Central Sprinkler Corp \\
\hline
\end{tabular}




\begin{tabular}{|c|c|}
\hline 19990616 & CBS Corp \\
\hline 19990621 & Abbott Laboratories \\
\hline 19990625 & Lucent Technologies Inc \\
\hline 19990625 & IBP Inc \\
\hline 19990701 & Lucent Technologies Inc \\
\hline 19990708 & CBS Corp \\
\hline 19990708 & Abbott Laboratories \\
\hline 19990712 & Walt Disney Co \\
\hline 19990714 & El du Pont de Nemours and Co \\
\hline 19990714 & General Electric Co \\
\hline 19990715 & Hewlett-Packard Co \\
\hline 19990720 & Sprint Corp \\
\hline 19990721 & Johnson \& Johnson \\
\hline 19990722 & CBS Corp \\
\hline 19990727 & IBM Corp \\
\hline 19990727 & Sprint Corp \\
\hline 19990804 & Chase Manhattan Corp, $\mathrm{NY}$ \\
\hline 19990804 & Hewlett-Packard Co \\
\hline 19990809 & EMC Corp \\
\hline 19990810 & Abbott Laboratories \\
\hline 19990811 & Procter \& Gamble Co \\
\hline 19990812 & General Mills Inc \\
\hline 19990816 & CBS Corp \\
\hline 19990818 & CBS Corp \\
\hline 19990823 & Tyco InternationalLtd \\
\hline 19990826 & Procter \& Gamble Co \\
\hline 19990831 & Sprint Corp \\
\hline 19990901 & CBS Corp \\
\hline 19990909 & Hewlett-Packard Co \\
\hline 19990920 & Hewlett-Packard Co \\
\hline 19990927 & CBS Corp \\
\hline 19990928 & Chase Manhattan Corp,NY \\
\hline 19991004 & CBS Corp \\
\hline 19991005 & El du Pont de Nemours and Co \\
\hline 19991005 & El du Pont de Nemours and Co \\
\hline 19991006 & CBS Corp \\
\hline 19991008 & El du Pont de Nemours and Co \\
\hline 19991008 & El du Pont de Nemours and Co \\
\hline 19991011 & Berkshire Hathaway Inc \\
\hline 19991013 & Chase Manhattan Corp, $\mathrm{NY}$ \\
\hline 19991019 & Citigroup Inc \\
\hline 19991019 & Sprint Corp \\
\hline 19991021 & America Online Inc \\
\hline 19991022 & Sprint Corp \\
\hline 19991026 & Tyco InternationalLtd \\
\hline 19991101 & AT\&T Corp \\
\hline 19991101 & EMC Corp \\
\hline 19991101 & Praxair Inc \\
\hline
\end{tabular}

ThirdAge Media Inc

ALZA Corp

Nexabit Networks Inc

Thorn Apple Valley Inc

CCOM Information Systems

Medscape Inc

Perclose Inc

Infoseek Corp

El du Pont de Nemours and Co

Energy,Environmental Research

Diametrics Medical Inc

GST Telecommunications Inc

Centocor Inc

Rx.com

Mylex Corp

WBS America LLC-Operating

Mellon Financial Corp

Security Force Software Inc

Data General Corp

SangStat Medical Corp

IAMs Co

Gardetto's Bakery Inc

Wrenchead.com Inc

Jobs.com

General Surgical Innovations

Recovery Engineering Inc

Hybrid Networks Inc

Big Entertainment Inc

Digimarc Corp

Qosnetics

Women's Consumer Network

Hambrecht \& Quist Group Inc

CTC Bulldog Inc

CombiChem

CombiChem

iWon Inc

ImaRx Pharmaceutical Corp

ImaRx Pharmaceutical Corp

Jordan Furniture Co Inc

Hungtington-Credit Card Rec

Citigroup Inc

Videotron USA(Le Group Video)

Gateway Inc

Videotron Bay Area (Sprint)

Praegitzer Industries Inc

Firstcom Corp

Siros Technologies

Materials Research Corp 


\begin{tabular}{|c|c|c|}
\hline 19991103 & SBC Communications Inc & Radiofone Inc \\
\hline 19991104 & Pfizer Inc & Warner-Lambert Co \\
\hline 19991109 & Johnson \& Johnson & Innovasive Devices Inc \\
\hline 19991122 & Abbott Laboratories & Glaxo-Crt Anesthesia Bus Asset \\
\hline 19991201 & El du Pont de Nemours and Co & Chematch.com \\
\hline 19991201 & Abbott Laboratories & SpectRx Inc \\
\hline 19991210 & Boeing Co & SkyBridge LP (Alcatel Alsthom) \\
\hline 19991215 & General Mills Inc & Small Planet Foods \\
\hline 19991215 & General Mills Inc & Small Planet Foods \\
\hline 19991221 & IBP Inc & Corporate Brand Foods America \\
\hline 19991221 & EMC Corp & Softworks Inc \\
\hline 19991222 & America Online Inc & MapQuest.com Inc \\
\hline 19991229 & CBS Corp & SportsLine USA Inc \\
\hline 19950104 & Johnson and Johnson & Mitek Surgical Products \\
\hline 19950426 & Johnson and Johnson & Joint Medical Products Corp \\
\hline 19950605 & International Business Machines & Lotus Development Corp \\
\hline 19950706 & F Hoffman-La Roche (Roche HIdg) & American Home Products \\
\hline 19950815 & Bristol Myers Squibb & Somatix Therapy Corp \\
\hline 19950816 & Bristol Myers Squibb & Somatix Therapy Corp \\
\hline 19950829 & Johnson and Johnson & GynoPharma Inc \\
\hline 19950911 & International Business Machines & Early, Cloud \& Co \\
\hline 19950918 & Abbott Laboratories & Ligand Pharmaceuticals, Inc. \\
\hline 19950921 & Hewett Packard Co & Convex Computer Corp \\
\hline 19950929 & SBC Communications, Inc. & Kacol Cellular-Rochester, NY MS \\
\hline 19951019 & Johnson and Johnson & Cordis Corp \\
\hline 19951030 & AT\&T Corp & IVI Publishing Inc \\
\hline 19951102 & American Home Products & Immunex Corp \\
\hline 19951117 & AT\&T Corp & Time Warner Cable Corp \\
\hline 19951220 & International Business Machines & Taligent Inc (IBM, Apple) \\
\hline 19951221 & Hewett Packard Co & ElseWare Corp \\
\hline 19960122 & AT\&T Corp & DirecTV \\
\hline 19960131 & International Business Machines & Tivoli Systems Inc \\
\hline 19960315 & Winn-Dixie Stores, Inc & AW Computer Systems Inc \\
\hline 19960329 & Abbott Laboratories & MediSense Inc \\
\hline 19960401 & International Business Machines & Wilkerson Group \\
\hline 19960513 & General Electric Co & Electric Insurance Co \\
\hline 19960620 & Hewett Packard Co & Division Inc \\
\hline 19960708 & Johnson and Johnson & Pharmacy Fund \\
\hline 19960709 & Hewett Packard Co & DP-TEK Development Co-Certain \\
\hline 19960711 & Ford Motor Co. & Budget Rent-A-Car Corp \\
\hline 19960808 & Eastman Kodak Co Inc & Fox Photo Inc (CPI Corp) \\
\hline 19960813 & International Business Machines & CPM Corp-Target Software Sys \\
\hline 19960912 & Gillette Company & Duracell International Inc \\
\hline 19960930 & Eastman Kodak Co Inc & American Stores-Photo Labs (3) \\
\hline 19960930 & International Business Machines & Professional Data Mgmt Assoc \\
\hline 19961007 & Johnson and Johnson & Indigo Medical Inc \\
\hline 19961017 & Phillip Morriss Companies & PepsiCo Inc \\
\hline 19961101 & Exxon/Mobil Corp & Southwest Petro-Chem-Grease \\
\hline
\end{tabular}




\begin{tabular}{|c|c|c|}
\hline 19961113 & International Business Machines & Edmark Corp \\
\hline 19961212 & The Proctor and Gamble Company & Regeneron Pharmaceuticals Inc \\
\hline 19961217 & Boeing Corp & McDonnell Douglas Corp \\
\hline 19961223 & American International Group & Alcohol Sensors International \\
\hline 19970211 & Johnson and Johnson & Innotech Inc \\
\hline 19970218 & $\begin{array}{l}\text { E. I. DuPont de Nemours and } \\
\text { Company (DuPont) }\end{array}$ & Pfister Hybrid Corn Co \\
\hline 19970310 & General Electric Co & Greenwich Air Services Inc \\
\hline 19970319 & International Business Machines & NetObjects Inc \\
\hline 19970401 & General Electric Co & ICS Holdings Inc \\
\hline 19970408 & American International Group & Golden Eagle Insurance Co \\
\hline 19970409 & The Proctor and Gamble Company & Tambrands Inc \\
\hline 19970508 & International Business Machines & Advantis (IBM, Sears Roebuck) \\
\hline 19970522 & Johnson and Johnson & Biopsys Medical Inc \\
\hline 19970725 & General Electric Co & Liberty Tech-Nondestructive \\
\hline 19970804 & Johnson and Johnson & Gynecare Inc \\
\hline 19970807 & $\begin{array}{l}\text { E. I. DuPont de Nemours and } \\
\text { Company (DuPont) }\end{array}$ & Pioneer Hi-Bred International \\
\hline 19970821 & $\begin{array}{l}\text { E. I. DuPont de Nemours and } \\
\text { Company (DuPont) }\end{array}$ & Protein Technologies Intl \\
\hline 19970923 & Hewett Packard Co & ForeFront Grp-Internet Tech \\
\hline 19971111 & Hewett Packard Co & Nuview Inc-Nuview Managex \\
\hline 19971112 & International Business Machines & Technology Svc Solutions (IBM) \\
\hline 19971215 & General Electric Co & Cal Tech Controls \\
\hline 19971222 & American International Group & American Bankers Ins Group Inc \\
\hline 19971229 & Hewett Packard Co & Heartstream Inc \\
\hline 19980105 & General Electric Co & Marketing Services Group Inc \\
\hline 19980121 & General Electric Co & Lockheed Martin-Bus Units(2) \\
\hline 19980311 & International Business Machines & General Elec Capital Svcs-Coml \\
\hline 19980406 & Lucent Technologies Inc & Chip Express Corp \\
\hline 19980518 & Coca-Cola Enter(Coca-Cola Co) & Inforum Office Building, GA \\
\hline 19980519 & International Business Machines & Databeam Corp \\
\hline 19980601 & American Home Products & Monsanto Co \\
\hline 19980720 & PepsiCo, Inc & Tropicana Products Inc \\
\hline 19980721 & Johnson and Johnson & Depuy Inc (Corange Ltd) \\
\hline 19980721 & General Electric Co & Raytheon Systems Ltd Flight \\
\hline 19980728 & Lucent Technologies Inc & MassMedia Commun (Lucent) \\
\hline 19980730 & American International Group & Blackstone Group \\
\hline 19980803 & General Electric Co & Power Factor Correction \\
\hline 19980820 & American International Group & SunAmerica Inc \\
\hline 19981005 & Johnson and Johnson & FemRx Inc \\
\hline 19981006 & Lucent Technologies Inc & Quadritek Systems Inc \\
\hline 19981120 & Phillip Morriss Companies & Liggett Group-Cigarette Lines \\
\hline 19981124 & Lucent Technologies Inc & Pario Software Inc \\
\hline 19981201 & Exxon/Mobil Corp & Mobil Corp \\
\hline 19981203 & Automatic Data Processing Inc & Vincam Group Inc \\
\hline 19981217 & Johnson and Johnson & SC Johnson \& Sons Inc-Skin \\
\hline 19981223 & Chevron Corp & Rutherford-Moran Oil Corp \\
\hline
\end{tabular}


19990113 Lucent Technologies Inc

19990208 SBC Communications, Inc.

19990309 International Business Machines

19990317 General Electric Co

19990414 AT\&T Corp

19990416 General Electric Co

19990422 AT\&T Corp

19990609 International Business Machines

19990615 America Online

19990629 Lucent Technologies Inc

19990630 Wal-Mart Stores Inc

19990712 International Business Machines
Ascend Communications Inc Williams Communications Group

Red Hat Inc

Advanced Lighting Technologies

Dobson Communications Corp

ValueVision International Inc

MediaOne Group Inc

Whistle Communications Corp

Digital Marketing Services Inc

Cirent Seniconductor

Federal Bank Center, OK

Sequent Computer Systems Inc 


\section{Table 3}

Country and Size Effects on Abnormal Returns for German and U.S. Acquirer Firms

The tables report cross-section regressions where the dependent variables are firm-level abnormal returns. Independent variables include dummy variables for whether the firm is German or U.S. Interactive terms with dummy variables for big firms having a market capitalization of over $\$ 25$ billion in Germany or $\$ 75$ billion in the U.S. are included to test whether the abnormal returns are different for big firms versus smaller firms.

\section{a) Cumulative Abnormal Returns Before Merger News Day (day -5 to -1 )}

\begin{tabular}{|l|l|l|}
\hline Variable & Coefficient & P-value \\
\hline German & 0.132 & 0.00 \\
\hline German*Big & 0.158 & 0.00 \\
\hline US & -0.050 & 0.00 \\
\hline US*Big & 0.197 & 0.05 \\
\hline & & \\
\hline R-squared & 0.687 & \\
\hline
\end{tabular}

\section{b) Abnormal Returns on Merger News Day}

\begin{tabular}{|l|l|l|}
\hline Variable & Coefficient & P-value \\
\hline German & 0.092 & 0.00 \\
\hline German*Big & 0.158 & 0.00 \\
\hline US & 0.005 & 0.06 \\
\hline US*Big & 0.202 & 0.00 \\
\hline & & \\
\hline R-squared & 0.678 & \\
\hline
\end{tabular}

c) Cumulative Abnormal Returns After Merger News Day (day +1 to +5$)$

\begin{tabular}{|l|l|l|}
\hline Variable & Coefficient & P-value \\
\hline German & -0.059 & 0.00 \\
\hline German*Big & 0.132 & 0.00 \\
\hline US & 0.174 & 0.00 \\
\hline US*Big & 0.162 & 0.00 \\
\hline & & \\
\hline R-squared & 0.623 & \\
\hline
\end{tabular}


Table 4

Country, Size, and U.S.-Listing Effects on Abnormal Returns for German and U.S. Acquirer Firms

The tables report cross-section regressions where the dependent variables are firm-level abnormal returns. Independent variables include dummy variables for whether the firm is German or U.S. Interactive terms with dummy variables for big firms and dummy variables for German firms that report financial statements conforming to U.S. GAAP are included to test whether the abnormal returns are different for big firms versus smaller firms or for German firms that must meet U.S. disclosure standards to be traded on a U.S. exchange.

\section{a) Cumulative Abnormal Returns Before Merger News Day (day -5 to -1 )}

\begin{tabular}{|l|l|l|}
\hline Variable & Coefficient & P-value \\
\hline German & 0.132 & 0.00 \\
\hline German*USlist & -0.057 & 0.00 \\
\hline German*Big & 0.146 & 0.00 \\
\hline US & -0.042 & 0.00 \\
\hline US*Big & 0.210 & 0.00 \\
\hline & & \\
\hline R-squared & 0.690 & \\
\hline
\end{tabular}

\section{b) Abnormal Returns on Merger News Day}

\begin{tabular}{|l|l|l|}
\hline Variable & Coefficient & P-value \\
\hline German & 0.098 & 0.00 \\
\hline German*USlist & 0.002 & 0.00 \\
\hline German*Big & 0.165 & 0.00 \\
\hline US & 0.021 & 0.00 \\
\hline US*Big & 0.202 & 0.00 \\
\hline & & \\
\hline R-squared & 0.748 & \\
\hline
\end{tabular}

c) Cumulative Abnormal Returns After Merger News Day (day +1 to +5 )

\begin{tabular}{|l|l|l|}
\hline Variable & Coefficient & P-value \\
\hline German & -0.054 & 0.00 \\
\hline German*USlist & 0.101 & 0.00 \\
\hline German*Big & 0.166 & 0.00 \\
\hline US & 0.135 & 0.00 \\
\hline US*Big & 0.202 & 0.00 \\
\hline & & \\
\hline R-squared & 0.755 & \\
\hline
\end{tabular}




\section{Figure 1a Cumulative Abnormal Returns for German Acquiring Firms}

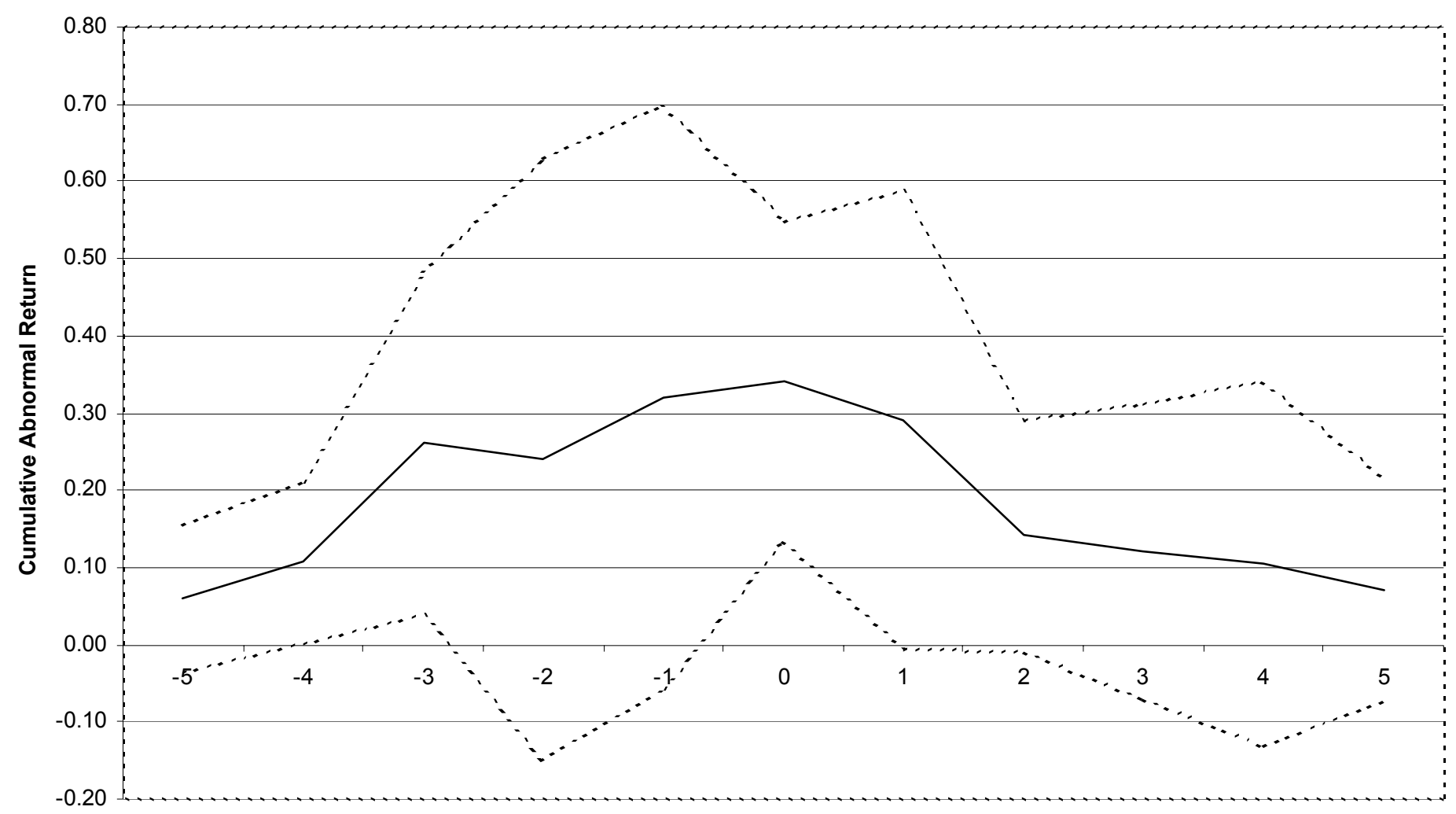

Day 


\section{Figure 1b Cumulative Abnormal Returns for U.S. Acquiring Firms}

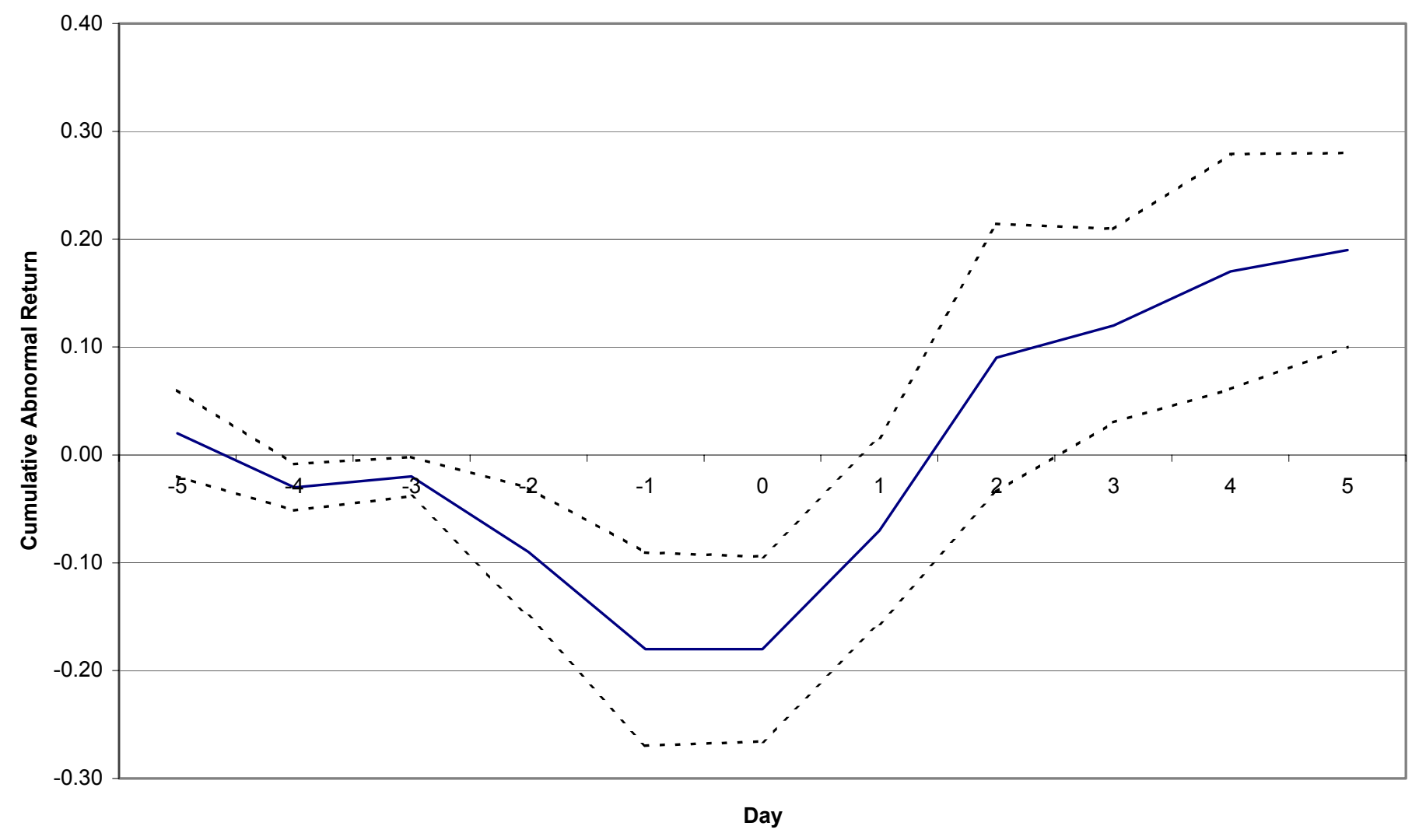

